\title{
We Are All Supply-Siders Now!
}

\author{
JOHN A. TATOM
}

\begin{abstract}
$\mathrm{T}_{\mathrm{H}}$ latest sensation in the popular press and among policymakers is the discovery of "supply-side economics" and the exciting promise of supply-side policies. ${ }^{1}$ To provide a perspective on the current debate, this article reviews the conceptual basis for supply-side economics and examines the fundamentals of supply performance in the United States.
\end{abstract}

\section{WHAT IS SUPPLY-STOE ECONOMICS ALL ABOUT?}

Supply-side economics is growth- and efficiencyoriented. It covers the entire range of economic decisions: what gets produced, how, for whom, and how fast production and consumption possibilities expand. The supply-side approach is not novel in economic analysis. Indeed, it has been the core of economic analysis since the first systematic analysis of scarcity and aggregate supply, Adam Smith's pioneering Inquiry into the Nature and Causes of the Wealth of Nations, was published over 200 years ago. ${ }^{2}$

The recent emphasis on supply is novel, however, in at least one respect - the assertion that supply

\footnotetext{
Tone of the first major policymaking endorsements of supplyside economics is contained in Outlook for the $1980^{\circ} \mathrm{s}$, Midyear Report and Staff Study of the Joint Economic Committee of the Congress (August 1979).

For an historical perspective on supply-side economics, see Robert E. Keleher and William P. Orzechowski, "Stupply-Sile Effects of Fiscal Policy: Some Historical Perspectives," re. viewed in the Federal Reserve Bank of Atlanta Economic Review (February 1981), pp. 26-28.
}

effects are of central importance in evaluating government efforts to improve the functioning of the economy. The conventional view of the functioning of the economy emphasizes a role for the management of aggregate demand as an appropriate macroeconomic policy for stabilizing the economy. The normal tools for influeneing aggregate demand are monetary and fiscal policy, including spending for goods and services, transfer programs and taxation policies. By influencing demand for output, such policies are presumed to affect the levels of the nation's output, employment and prices, as well as their rates of change. Expanding the growth of the money stock or government expenditures for goods, services or transfer programs is viewed as "expansionary" in its effects on output and employment. Supply-siders reject such arguments as woefully incomplete. They emphasize that standard expansionary macroeconomic policies can significantly reduce the economy's ability to produce. In particular, they stress that individual choices affect the current and future availability of resources, as well as the efficiency of resource employment, effects that often are ignored in both macroeconomic analysis and policy decisions.

The supply-side view can be explained using a simple introductory economics framework. Suppose an economy has a given quantity of resources such as labor and capital (plant, equipment, knowledge, etc.) and an existing array of technologies for producing two goods called product $\mathrm{X}$ and product $\mathrm{Y}$. At any time, resources can be completely devoted to the production of one or the other good, or both. If resources are 


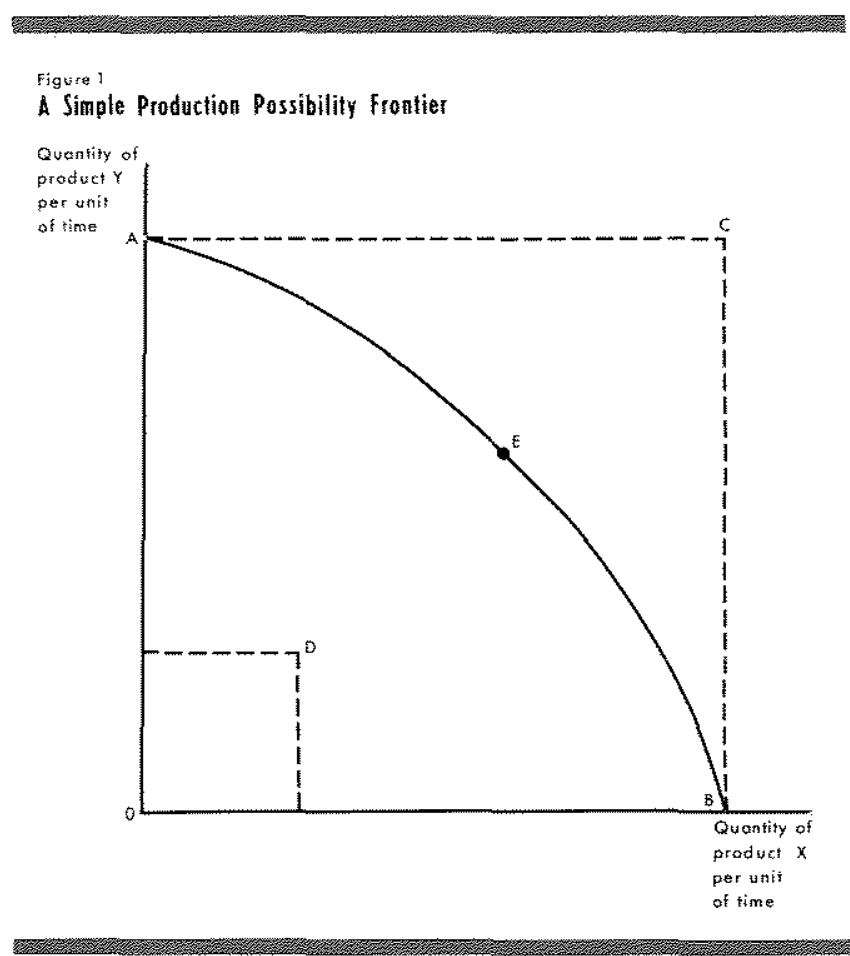

used so that the largest production of $\mathrm{X}$ is obtained, for any given output of product $Y$, the production and consumption possibilities of the economy can be depicted as the curve $A B$ in figure 1. Combinations of product $X$ and $Y$ output beyond $A B$ (such as point $C$ ) are unattainable, given the technology and resources available, while those inside the curve (such as point D) are possible, but involve either unemployed resources, the use of inferior technologies, or both.

Given individual preferences and the distribution of resource ownership among individuals, an economy with free markets will tend to attain some equilibrium point $(\mathrm{E})$, where the value of goods reflects the cost of production and where full employment of existing resources occurs. Competition among resource owners, the producers of the two goods and consumers will determine the prices of the products and resources, how much of each of the goods are produced, which of the available resources and technologies are used to produce each good, the incomes of individuals, and the distribution of goods produced among individuals.

An economy can improve its possibilities for consumption by shifting out its production possibility frontier ( $A B$ in figure 1). This occurs when the supply of labor or capital resources is increased or when technology is improved. Thus, individuals make choices that determine the rate of growth of income or the supply of goods producible under high-employment conditions. These choices involve foregoing pres-

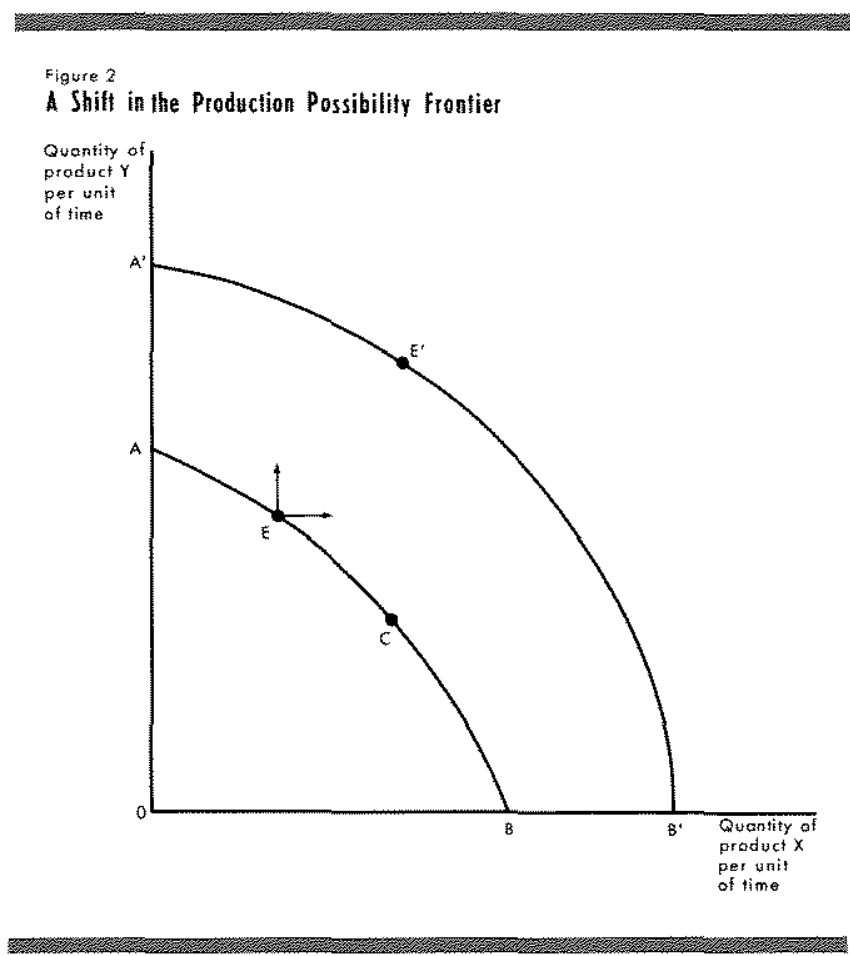

ent consumption so that resources can be used for research and development, innovation or the production of new capital goods. Figure 2 shows such a shift in production (and consumption) possibilities. When the production possibility frontier shifts from $A B$ to $A^{\prime} B^{\prime}$, individuals choose the opportunity to consume an output mix such as $\mathrm{E}^{\prime}$.

Supply-side economics focuses on two aspects of the simple framework above: first, that economic policy directly affects the rate of growth of resource supplies and the pattern of innovation, impinging on the rate at which the economy's production possibilities improve; second, that economic policy can alter the position of the current production possibility frontier. ${ }^{3}$

\section{Supply-Side Effects of Regulation}

Economic policies to regulate business can affect supply. In a market economy, the government can promote efficiency by regulating efforts to achieve monopoly control in resource or product markets. Such regulatory policies can also promote faster output growth by policing business practices that limit competition, technological development and innovation.

A detailed discussion of the supply-side approatch to macroeconomic policy may be found in Laurence $H$. Meyer, ed. The Supply-Side Effects of Economic Polion (Center for the Study of American Business and the Federal Reserve Bank of St. Louis, 1981). 
Regulatory policies can adversely affect consumption possibilities, however. Regulatory programs that mandate the use of inefficient technologies or that restrict the use of resources in some or all production processes cause the production possibility frontier to shift inward (for example, from $A^{\prime} B^{\prime}$ to $A B$ in figure 2 ). Such regulations can slow the rate of growth by retarding technological innovation or by reducing incentives to accumulate resources or improve their quality.

\section{Supply-Side Effects of Government Spending}

The decision to provide more of one good through government provision involves attracting resources away from the production of other goods (a movement along the production possibility frontier). Supply-siders emphasize, however, that the increased taxes levied to pay for the new goods can reduce the total resources available, shifting the frontier inward. Suppose the economy is initially producing and consuming at point $E^{\prime}$ in figure 2. An attempt by the government to increase the output of good $\mathrm{X}$, moving along the frontier $A^{\prime} B^{\prime}$, can lead to fewer available resources so that (1) the frontier shifts inward to a new frontier such as $\mathrm{AB}$, and (2) production occurs at a point like $\mathrm{C}$. The shift occurs because owners of human resources can forego supplying these resources in the marketplace, choosing instead to use labor resources at home or in leisure when confronted with larger taxes on labor income. Similarly, owners of capital resources can avoid taxes by reducing the use of existing plant and equipment, lengthening the useful life of assets, and spending the proceeds from current use of capital services on consumer goods instead of replacing the plant and equipment or investing in new assets. In the case of taxation of income of capital resources, the effects on the production possibility frontier tend to show up more heavily in the future through reduced growth of resources, rather than in immediate inward shifts of the frontier.

Taxation can also give rise to other forms of tax avoidance that shift the frontier inward. When taxes on resource incomes are different depending on the use of the resources, resource owners may continue supplying resources in the marketplace, but divert these resources to lower-taxed, less-efficient uses, While this lowers the total productivity of the resources, the after-tax incomes are larger than they would have been if resources were used in the high-tax sectors. Such tax avoidance leads to an inward shift of the frontier, even if the total supplies of resources remain the same.

\section{Stipplyside Efects of Redistribution}

Similarly, an economic policy aimed at changing the distribution of consumption goods among individuals can affect supply. A program that taxes income recipients in order to transfer existing output to particular groups can reduce the total consumption possibilities of the community. For example, increased unemployment benefits, food stamps and social security benefits involve increased transfers and taxes. Higher taxes can reduce the supply of resources available both now and in the future; in addition, higher transfer payments reduce some individuals' incentives to accumulate and stpply resources in the marketplace. Both the programs and the higher taxes to support them can reduce resource supplies. ${ }^{4}$ Reductions in resource employment reduce output. Government policies to transfer more of the goods produced at point $\mathrm{E}$ in figure 1 to a particular group can shift the overall production and consumption possibilities of the economy inward, as the higher taxes to pay for the redistributed goods and the increased availability of transfer payments reduce the total resources available for use in production.

Supply-siders emphasize that the critical factor in government transfer and spending decisions is that such expenditures are financed either by taxation, borrowing from the public or increasing the money supply, These methods of finance lead to reductions in the total supply of resources available for production. Higher tax rates discourage individuals from work, saving and productive investment. Financing through government deficits (borrowing), simply postpones taxes and "crowds out" private-sector investment in plant, equipment and consumer durables such as housing and autos, as financing costs are raised.

\section{Supply-Side Effects of Monetary Policy}

Attempts to finance expenditures by printing money similarly reduce the nation's production possibilities. A faster rate of money growth increases the rate of inflation (the rate at which the value of money declines). Inflation interferes with economic efficiency. For example, it creates uncertainties about the meaning of price changes. When a product's price is raised or when wages in an industry rise, it is

\footnotetext{
4These considerations do not imply an aversion to redistribution schemes on the part of supply-siders. From a strictly positive riew, however, supplynsiders would tend to emphasize that the nation's distributional objectives can be accomplished more or less efficiently depending on the supply-side incentives involved.
} 
less clear whether the increase reflects the scarcity of the product or resource, or the inflation process. Inflation also distorts the allocation of resources, as people enploy scarce resources to economize on the higher cost of holding money. The disproportionate growth of resource employment in banking, financial intermediaries and financial management services is an example of such an inefficiency.

The supply-side effects of inflation also arise through the U.S. tax system. The principal characteristic of the tax system that creates supply-side disincentives when inflation occurs is its basis on historical nominal accounting of income. For the individual income tax, this has two important implications. First, when inflation is higher, investors require higher rates of return to compensate for the erosion of purchasing power of both future interest payments and the original sum loaned. These higher interest rates simply allow the maintenance of the purchasing power of investors' portfolios. The added interest is compensation for a maintenance expense, not income. Nonetheless, these higher interest payments are taxed as income. The higher taxes on these non-income payments reduce the incentives to save and invest.

Second, the individual income tax is applied against nominal income in a progressive fashion. As a result, when wages and other income simply keep pace with inflation, individuals find themselves in higher and higher tax brackets, so that the purchasing power of their income declines. This process, sometimes called "bracket creep," subjects individuals to increasingly higher taxes on existing and any prospective additions to purchasing power. Consequently, workers have less incentive to work or save, despite the tendency of wages to keep pace with inflation.

For business, tax accounting again is based on historical nominal magnitudes. Thus, inventory expenses and depreciation are computed on the basis of the past dollar expenditures on goods, equipment or plant, instead of the current dollar costs of replacing the inventory or plant and equipment currently being used up in production. As a result, inflation leads to an understatement of the true costs and therefore an overstatement of business income and artificially inflated taxes. Since historical cost accounting subjects a given real cash flow of a business to higher taxes, businesses are discouraged from adding new productive assets during inflationary periods. Of course, the result of reduced savings and investment is to slow the pace at which the production possibility frontier shifts outward. For a given labor force, the growth of output per worker slows.

\section{SUPPLI-SDE POLICY MMLICATIONS AND PROPOSA}

An immediate policy concern of supply-siders is to redress the destructive effects of policies created by demand management and regulatory strategies over the post-war era, particularly since the early 1960 s. This redress involves slower monetary expansion, regulatory reform, tax reduction and tax reform that reduce the disincentives to produce, work, save and invest.

To deal with the disincentives created by inflation, many supply-siders recommend indexing the tax system. For example, replacement cost accounting would permit firms to deduct from receipts the true cost of depreciation in computing income, avoiding the disincentives to invest posed by inflation. Second, inflation premia in interest rates could be excluded from taxation for firms and individuals. Finally, tax brackets for computing the individual income tax can be tied to the inflation rate to avoid bracket creep.

To reverse the disincentives created by past policy, some policymakers influenced by supply-side economics have recommended large reductions in tax rates on additional individual income, specifically a Kemp-Roth tax rate cut of 10 percent per year for 3 years. To reverse disincentives due to under-depreciation in the past, they have recommended a "10-5-3" capital cost recovery plan that accelerates the depreciation of physical assets to 10 years for structures, 5 years for business equipment and 3 years for cars and trucks used by business. Since capital expenditures under this plan are deducted from receipts as an expense sooner than otherwise, the additional income accruing from new capital expenditures is smaller in the earlier years of the life of an asset and larger later on. For the same additional receipts over the useful life of an asset, measured income is unaffected by accelerated depreciation; less of the income, however, is measured in the early years, while more is measured later. Therefore, taxes on income from assets are postponed, providing a greater incentive to invest today.

These two tax proposals have been the subject of controversy for several years. The intensity of the debate has increased dramatically since the proposals became the centerpiece of the initial tax package of the Reagan administration. It is ironic that the debate has become so tightly linked to arguments about 
supply-side economics. While both of these proposals arose out of concem for the disincentive effects of bracket creep and historical cost depreciation in an inflationary environment, neither confronts the source of the disincentive - nominal income taxation. Instead, both are aimed at redressing the disincentives created by past inflation.

The Kemp-Roth plan focuses on the importance of cutting "marginal tax rates," the rates applied on additional income, instead of simply cutting average tax rates. This distinction is of critical importance to supply-siders. The average tax rate is simply the total tax paid divided by the tax base, the adjusted gross income in the case of the individual federal income tax. For the income tax, the tax rate (marginal) on successive dollars of income is a rising percentage of additional income. The tax rate applied to additions to income (marginal rate) exceeds the average tax paid at any level of income. The marginal tax rate is the rate that influences decisions to earn more income by increasing work or savings. A rise in the marginal rate from 20 percent to 30 percent means that an additional $\$ 100$ of income will net only $\$ 70$ after taxes instead of $\$ 80$, so the incentive to forego leisure or consumption to work or save to earn this $\$ 100$ is reduced.

Chart 1 shows measures of the marginal and average tax rates over the past two decades. The average tax rate has changed little over the years shown. Periodic tax reductions have offset the effect of bracket creep on the average tax bill. The marginal rate, however, has risen sharply since 1970 .

The Kemp-Roth proposal, however, does not legislate automatic insulation of marginal rates from the infation rate, a fundamental tenet of supply-side economics. Moreover, the "10-5-3" proposal, a simplifled accelerated depreciation plan, is unrelated to the continuing disincentives created through the use of historical cost accounting in an inflationary environment. ${ }^{5}$ Neither of these proposals insulate current or

5There are altemative proposals that reftect concern over these supply-side issues. For example, the Black Caucus proposes indexing tax rates on so-called eamed income while the Jorgenson-Auerbach plan embotied in Howse Resolution 2525 attempts to eliminate the effects of inflation on depreciation expenses and business tax burdens. On the former, See Bureau of National Affuirs, Inc. Daily Report for Executive, DER No. 82, April 29, 1981, p. LL-12; the Jorgenson Atrerbach proposal is discussed in Dale W. Jorgenson and Peter Navarro, "10-5-3: "Deeply Flawed" "and the accompanying editorial "Real De. preciation, Real Inflation," New York Times, May 5, 1981. Note that, unlike the President's proposals, these two prow posals are aimed at avoiding future supply-side effects of inflation but not at correcting for past disincentives. future taxes from the ravages of inflation.

Perhaps the greatest irony of the debate over these two proposals is that neither proposal is a path-breaking supply-oriented innovation. Many claim that such policies are unproven and that their effects are unknown. While this may be the case for some supplyoriented policies, it is untrue of the Kemp-Roth proposal or "10-5-3." Experiments with these two types of tax changes were the hallmark of the "New Economics" of the sixties. Much was written before and after such changes about their effectiveness. While supply-siders differ in the analytical approach to such tax changes, the evidence is certainly available.?

\section{THE SUPPLI.SIDE RECORD}

What has happened to the supply side of the economy during the last 30 years? A review of the record should show whether the changes in economic policy of the past two decades have yielded evidence of the disorders discussed by supply-siders. At the same time, such a review can indicate whether the removal of the disincentives accumulated in the past could radically affect the economy. There is no question that the growth of supply of the nation's output has slowed markedly, at least since 1973, in large part due to the stagnant growth of productivity. This stagnation is supply-related, in that it arises from the astronomical rise in the price of energy resources relative to the price of business output and consequent losses in economic capacity (an inward shift of the production

The spirit of the tax proposals in correcting for past inflation effects rather than breaking the link between inflation and tax rates cam be seen in Paul Craig Roberts, "For Supply-Siders, The Focus is Incentives," Washington Post, April 13, 1981, where it is emphasized that the administration plan ". . doesn't turn the tax clock back to 1965 , but it is a big step in the right direction." Roberts notes that the marginal rate faced by the median-income family of four was at most 17 percent in 1965 and a family with twice the median income faced, at most, a 22 percent rate. These figtres will rise to 32 percent and 49 percent, respectively, in 1984 , without the President's proposat, according to Roberts. These figures, Roberts notes, ignore social security and state taxes and their increase since 1965 .

TUnfortunately the existence of such evidence does not mean that it has been intensely scrutinized or, if it has been, that there is a consensus among policy analysts about the effectiveness of past policies. In the ease of accelerated depreciation, business tax cuts, or investment tax credits, debate usually centers more on the relative merits of the three. See, for example, Richard W. Kopcke, "The Efficiency of Traditional Investment Tax Incentives," Public Policy and Capital Formation, (Board of Governors of the Federal Reserve System, April 1981), pp. 163-75. There is little question that these three policies temporarily increase the pace of investment. Whether such tax cuts temporarily reduce the inflation rate as supply-side arguments imply, leave it unaffected, or raise it, as Keynesians might expect, has been largely neglected. 
Chart 1

\section{Personal Tax Rates in the United States}

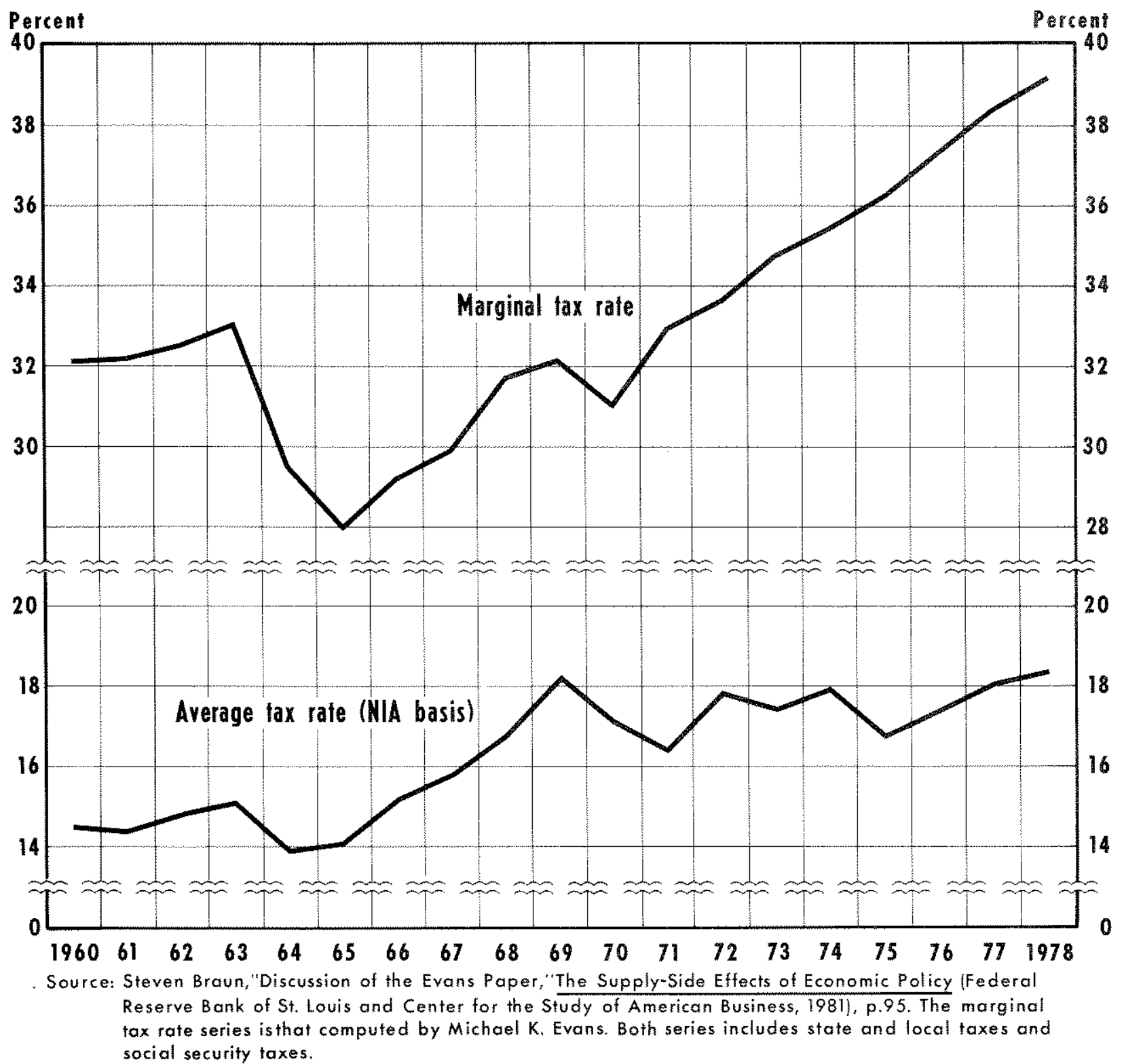

possibility frontier). This analysis has been detailed elsewhere, along with an examination of the potential contributions of traditional sources of productivity growth to this stagnation. ${ }^{8}$ The emphasis here is on the past macroeconomic policy effects on supply.

Chart 2 shows the civilian labor force and the stock of nonresidential private structures and equipment

8See John A. Taton, "The Productivity Problem," this Review (September 1979), pp. 3-16, and the references cited therein. available since $1947^{\circ}$ The civilian labor force has grown more rapidly since the mid-sixties. From 1948 to 1965 , the labor force expanded at a 1.2 percent annual rate. From 1965 to 1980 , it accelerated to a 2.3 percent rate. Capital stock growth shows about the same acceleration up until 1973. From 1948 to 1965,

9The stock of plant and equipment is the corstant dollar net stock of fixed non-residential private capital, see fohn $C$. Musgrave," "Fixed Capital Stock in the United States: Revised Estimates," Sturvey of Current Business (February 1981), pp. 57.68 . 


\section{Chort 2}

\section{Supply of Capital and Labor in the United States}

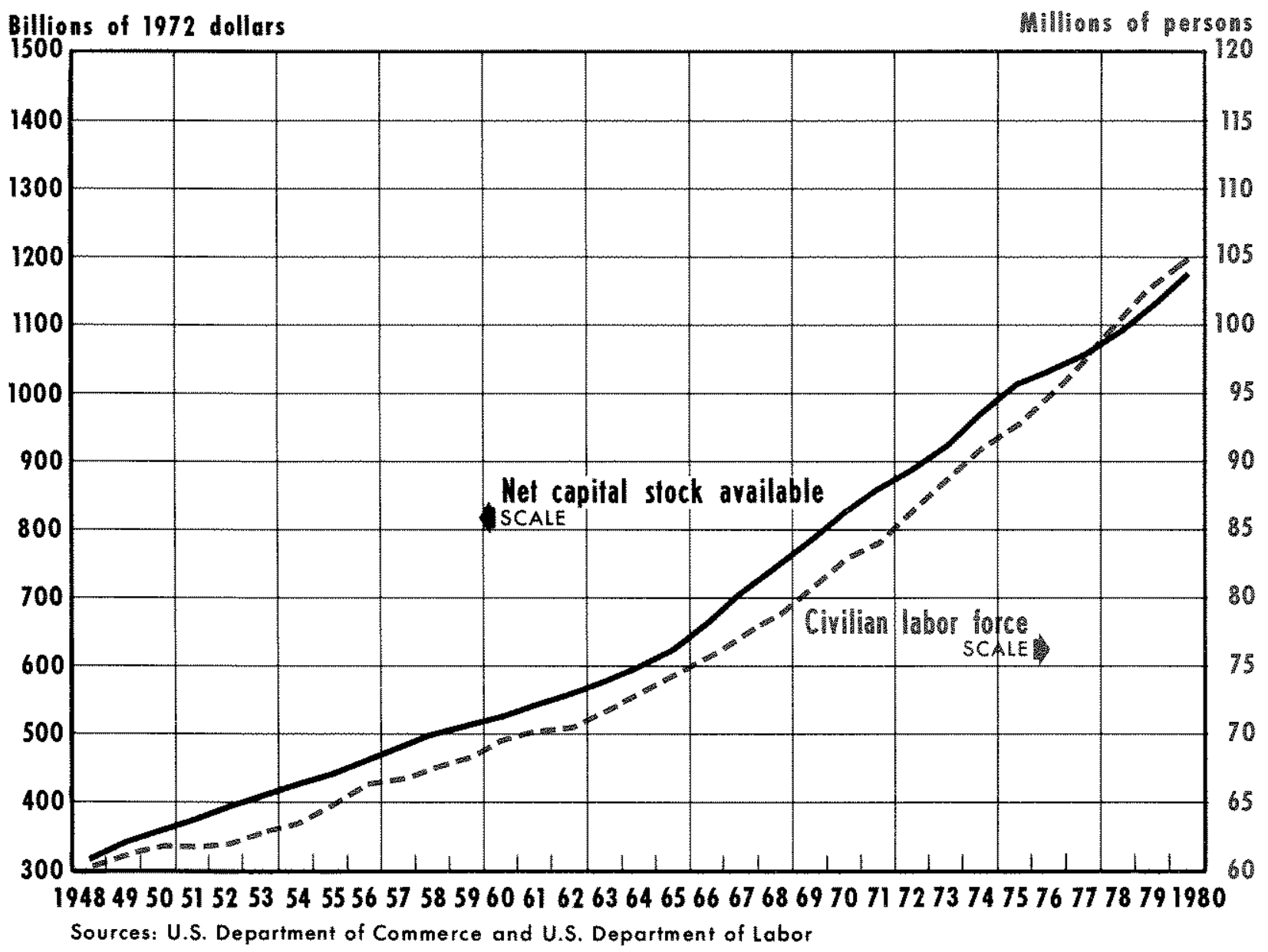

the stock of plant and equipment rose at a 4.1 percent rate. Such growth accelerated to a 4.9 percent rate from 1965 to 1975 , then dropped to a 3.0 percent rate from 1975 to 1980 .

Thus, when one looks at growth rates of available resources, there appears to be no major deterioration in the economy's aggregate supply until after 1975. Indeed, from 1965 to 1975 , supplies of resources were expanding much faster than before. The factors cited by supply-siders that reduce resource availability (such as the increasing regulation of both technology and the pattern of resource employment, inflation, rising marginal tax rates on income, and a growing share of government spending and transfer payments) do not seem to have seriously impaired resource availability, at least not before 1975 .

Although this analysis is crude, a more detailed analysis shows essentially the same patterns. In par- ticular, labor force growth is a crude measure of labor resource availability because it is heavily influenced by population trends rather than short-term economic factors. Supply-side policies can change the willingness of a given population of labor-force age to work by increasing their participation in the labor force or by increasing the effort of the labor force. Chart 3 shows the percentage of the population over age 16 in the labor force. There has been no apparent deterioration in overall participation in the labor force. ${ }^{10}$ Supply-side policies could also affect labor resource

\footnotetext{
10In a detalled study of the labor force participation rate, Leonall C. Andersen, "Are Explanation of Movements in the Labor Force Participation Rate: 1957 76," this Review (August 1978 ), pp. $7-21$, found that an individual income tax rate cut would have a small transitory effect of increasing the participation vate. He also observed that social security tax cuts would have small permanent effects, lowering participation, and that reduced social security benefits would have permanent effects raising participation.
} 
Chant 3

\section{Labor Force Participation Rate}

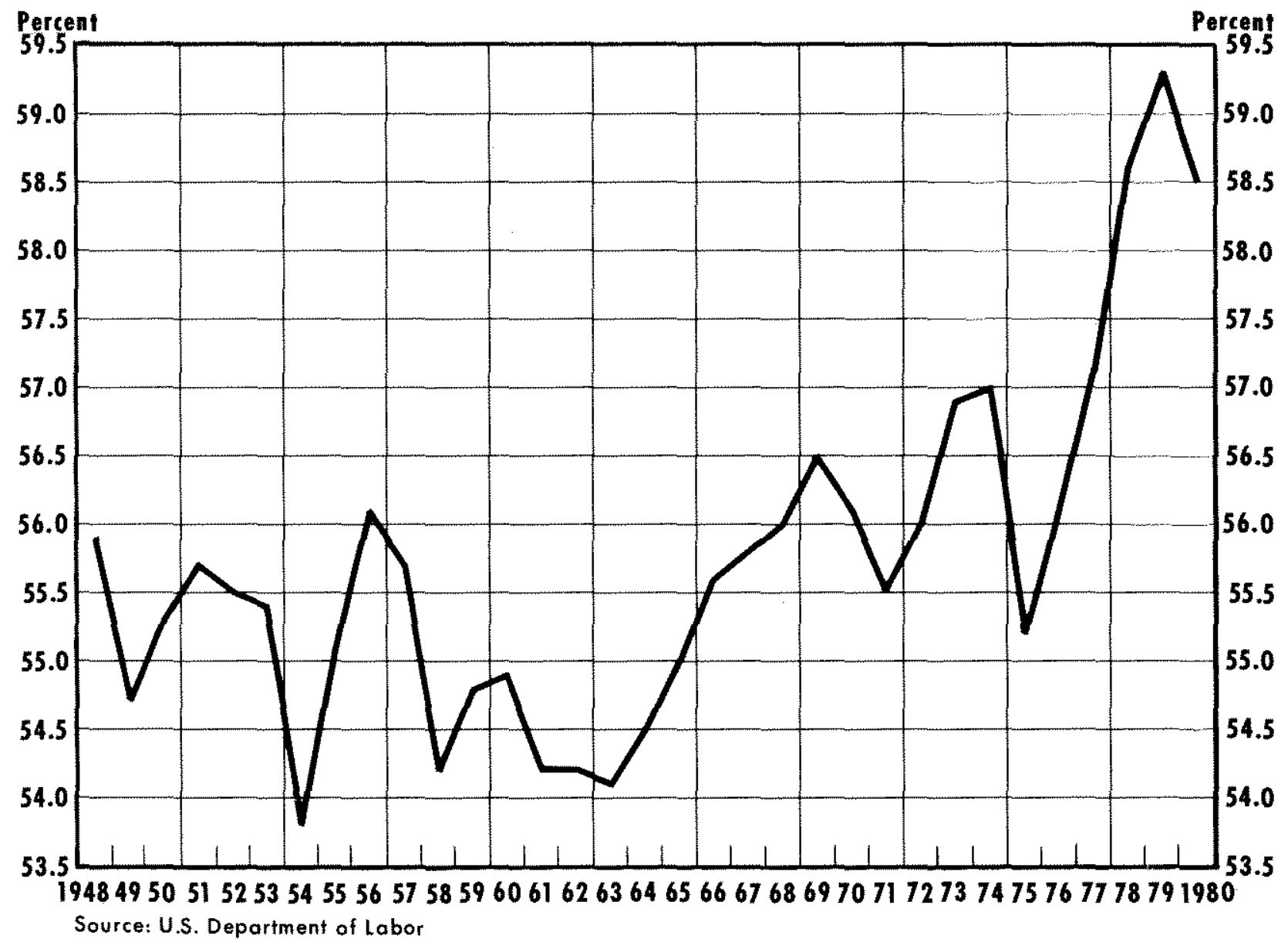

availability by altering the supply of work effort of a given labor force, for example, by changing the average hours worked per worker. Average hours worked have shown a significant downward trend throughout the post-World War II period, but this trend has not significantly accelerated in recent years. Nonetheless, studies of labor supply indicate that higher marginal tax rates have small negative effects on working hours, especially for wives with children. ${ }^{11}$

"See Jerry A. Hausman, "Labor Supply," in Henry J. Aaron and A. Joseph Pechman, eds, How Taxes Affect Economic Behavior (Brookings Institution, 1981), pg, 27-83. Detailed statistical analysis is required to support these results because the effect is relatively small, given the increases in marginal rates that have occurred in the post-war period. For reductions in marginal rates to 1965 levels, the tax effect on labor resource avallability would be correspondingly small and difficult to observe by simple statistical analysis. In addition, unless the reductions were repeated in subsequent years, the modest increase in hours would be of a once-and-for-all variety.
Finally, the available supply of labor need not have kept pace with the expansion of the labor force if the unemployment rate associated with full employment has risen significantly. While most analysts agree that the unemployment rate associated with high employment conditions has risen over the last 25 years, even the largest estimates of this increase would not reverse the pattern of accelerated labor resource growth shown in chart 2. More important, there is scant evidence that the rise in such a "full-employment" unemployment rate has been associated with growing supply-side disincentives. ${ }^{12}$ Some policies presumably lead to a withdrawal from the labor force

12See, for example, Daniel Hamermesh, "Transfers, Taxes, and the NAIRU," in The Supply Side Effects of Economic Policy. The NARU is the non-accelerating inflation rate of unemployment and is comparable to (ustally used as synonomous with) the "natural rate of unemployment," or the fullemployment unemployment rate. 


\section{Chart 4 \\ Federal Government Share of Output and Employment}

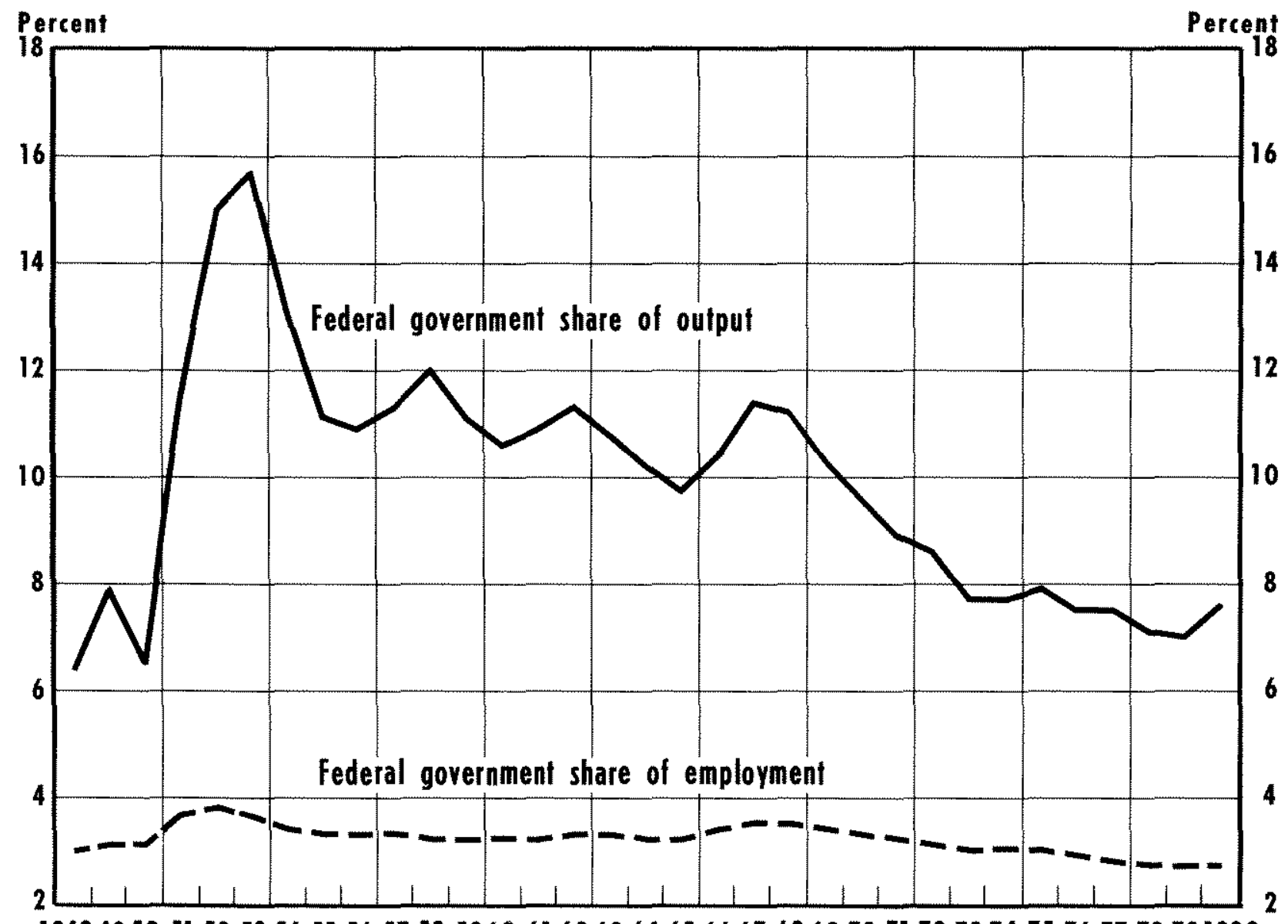

1948495051525354555657585960616263646566676869707172737475767778791980

Source: U.S. Department of Commerce and U.S. Department of Labor

of workers with relatively high unemployment rates while others lead to withdrawal of individuals with relatively low unemployment rates. An example of the former is the rising minimum wage that reduces opportunities for the young, resulting in their dropping out of the labor force. An example of the latter is the effect of an increasingly generous social security system that induces older workers who normally have a more favorable employment record to quit earlier. Changes in the composition of the labor force due to demographic changes have been the primary source of the increase in the full-employment unemployment rate.

Another factor often accused of creating supply-side problems is the rapid growth of government activity. The expansion of the role of government in the economy can draw resources away from the private sector where productivity growth tends to be greater. Thus, the rate at which the production and consumption possibility curve shifts could be lowered. This view, however, misstates the pattern of government growth in the economy in recent years. Chart 4 shows the share of federal government purchases of goods and services in total output (GNP) and the share of federal employment in civilian employment. Both of these measures peaked some years ago. ${ }^{13}$ It is difficult to

\footnotetext{
13The same pattern holds for state and local governments. The share of state and local govemment purchases of goods and services in CNP rose steadily until 1971 when it reached the 13 percent level. In $1973-75$, the share surged upward to over 14 percent and has subsequently declined to below 13 percent. Employees on state and local government payrolls as a percent of the civilian labor force also climbed steadily throughout the post-war period, peaking at about 13 percent in 1975 , then declining slightly.
} 
Chart 5

\section{Federal Government Expenditures and Transfer Payments as a Share of Output}

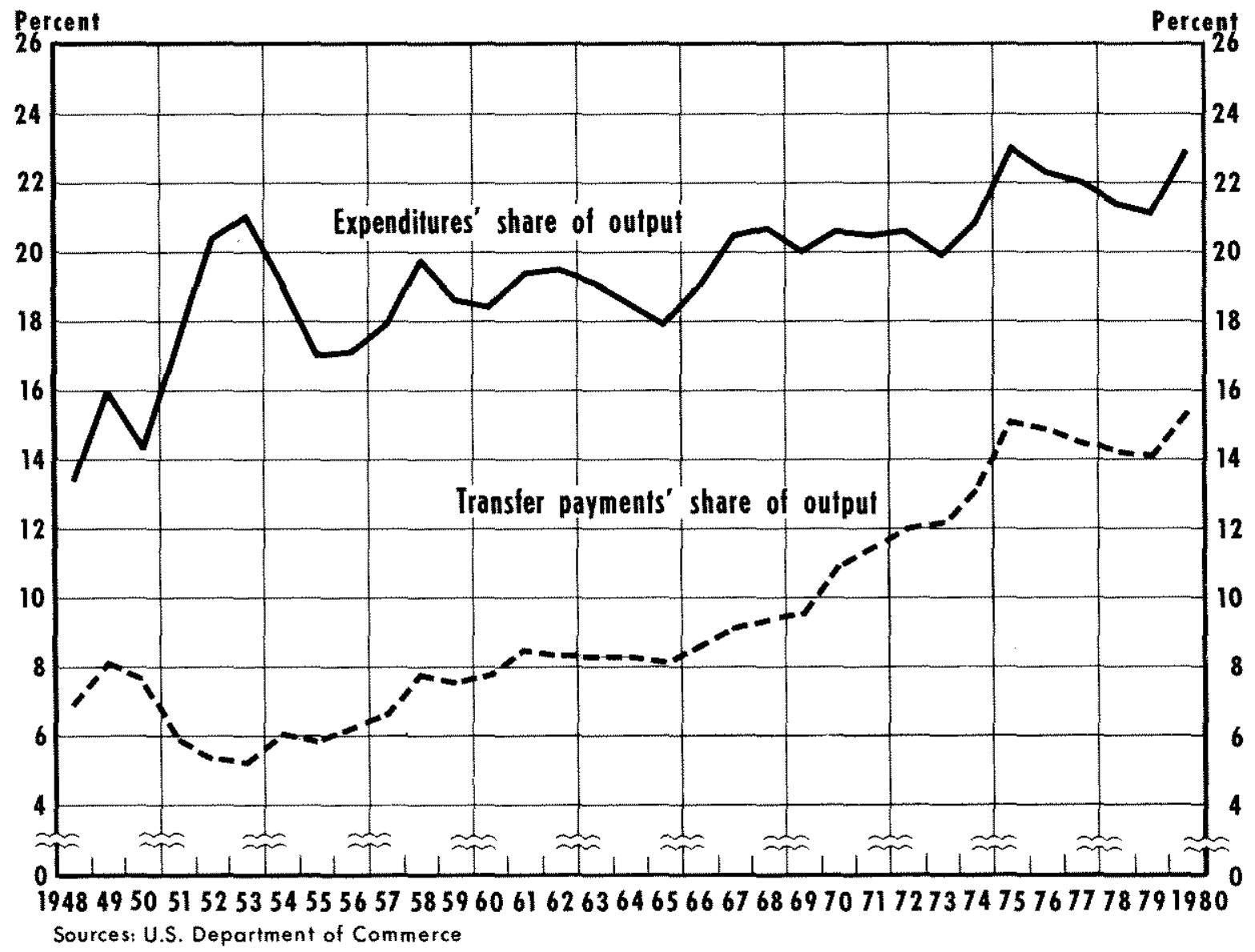

show that government has constrained output growth by altering the allocation of resources away from the private sector. ${ }^{14}$

How, then, has growth in the size of government adversely affected the supply side of the economy?

140ther forms of capital formation, including government, show the same slowing as that in the business sector. From 1960 to 1973 , the growth of the federal government capital stock was at a 1.1 percent rate; from 1973 to 1980 , this growth rate declined to a 0.4 percent rate. For state and local governments, the decline was from a 4.8 percent to a 2.0 percent rate from 1973 to 1980 . The growth of the residential housing stock decined from a 4.0 percent rate from 1948 to 1965 , to a 2.7 percent rate from 1973 to 1980 . Thus while inflation and the tax system combined to reduce capital formation in business and divert some capital fomation toward the housing sector, there was a slowing there. Even in owner-occupied housing, the sector with the greatest relative attractiveness, the growth rate of the housing stock declined from a 5.0 percent rate from 1948 to 1965 to a 3.2 percent rate from 1973 to 1980. See Musgrave, "Fixed Capital Stock" for data on these sectors.
Chart 5 shows the growth of federal government expenditures (purchases of goods and services plus transfer payments) and transfer payments alone, with both measured as a share of GNP. The share of expenditures has grown due to the extremely rapid growth of transfer payments. The growth in transfer payments is the only likely candidate as a major source of government disincentives for production and growth.

Moreover, it is this type of fiscal development over which there is the greatest difference between demand and supply analysts. Demand analysts presume that tax increases to pay for increased transfer payments simply redistribute purchasing power with no real effects on dernand, prices or aggregate output. From a supply analyst's view, such a policy produces a "double whammy," as both increased transfers and taxes provide disincentives to supplying resources in 
the market. But it must be emphasized that the trends in growth of resources do not indicate that the growing share of transfer payments has severely affected aggregate resource supplies.

\section{THE OUTLOOK FOR SUPPW Y.STE ETECTS}

While the past record does not indicate the possibility of revolutionary developments on the supply side of the economy, supply-oriented policies could modestly affect resource availability, economic effciency and growth. As noted earlier, for example, higher marginal tax rates have negative effects on work effort. Thus, reductions in marginal rates should increase labor resource availability. In addition, supply-side policies can have modest temporary effects on investment and productivity growth.

\section{Investment}

The growth of the capital stock accelerated mildly (chart 2) following a move toward accelerated depreciation and the introduction of the investment tax credit in 1962, and the cut in individual and business marginal tax rates in 1964-65. Similar actions in late 1971 also appear to have led to a mild subsequent acceleration. When the investment tax credit was suspended from October 1966 to March 1967 and again from April 1969 to December 1971, real producer durable investment slowed. From the third quarter of 1966 to the first quarter of 1967 , real investment in equipment declined at a 3.0 percent rate, substantially slower than the $\mathbf{1 4 . 1}$ percent rate of expansion over the prior year or the 16.7 percent rate of the prior two years. From the first quarter of 1969 to the fourth quarter of 1971, such investment slowed to a 3.7 percent rate of growth. Over the prior year, such investment had risen at a 10.1 percent rate; it rose at a 9.6 percent rate for the two years ending in the first quarter of 1969 . In the year following the end of each of these two suspensions, real investment in producer durables accelerated - to a 9.1 percent rate of growth in the first case, and to a 17.9 percent rate of growth in the second. From the end of 1962 to 1974 , the constant dollar net stock of private nonresidential fixed capital rose at a 4.8 percent rate, much faster than the 3.5 percent rate of the prior decade, or the 3.0 percent rate from end of 1974 to the end of 1980.

\section{Productivity}

Accelerations in capital formation affect productivity growth. Nonetheless, improvements in the quantity and quality of plant and equipment do not yield massive changes in aggregate productivity. Most estimates of the impact of faster growth of plant and equipment show that a 1 percent increase in the growth rate of the capital stock adds no more than 0.3 percent to the growth rate of productivity. Thus, a 3 percentage-point increase in the pace of capital formation, extremely large by historical standards, would likely add less than 1 percent to the rate of advance of output per worker, or output per hour.

Also, most programs to cut the cost of plant and equipment for firms or to increase returns from investing in new capital only temporarily affect capital formation. Essentially, such policies raise the optimal amount of plant and equipment available per worker. According to economic theory, investment will accelerate to reach the optimal proportions, but is subsequently unaffected. This is important because it indicates that any added productivity growth from supply-oriented policies is temporary.

\section{Inflation}

The greatest controversy concerning recent supplyoriented proposals concerns the effect on inflation. Some advocates of supply-side economics contend that supply-oriented policies will contribute to the elimination of inflation. ${ }^{15}$ The source of confusion in this analysis is a standard mark-up view of inflation that equates the inflation rate $(\dot{P})$ to the rate of increase in wage rates $(\dot{W})$, less the rate of productivity growth $(\dot{X})$. In this view, if productivity growth accelerates, then the rate of inflation slows (given the rate of increase in wages, $\dot{W}$ ). Even were this view correct, supply-oriented policies would provide little assistance for the anti-inflation effort. For the massive acceleration in capital formation and productivity growth in the example above, the pace of price increases would slow by less than 1 percentage point; even this gain would be as temporary as the acceleration in productivity growth.

But this mark-up view of inflation really has little to say about inflation. Instead, the equation tells something about the wedge between inflation of prod-

\footnotetext{
15See, for example, the analysis in the Joint Economic Comm mittee, Outlook for the 1980's, pp. 11-14.
} 
uct prices and the rate of increase in resource prices, especially prices of labor; that is, the rate of increase in the purchasing power of wages, $(\stackrel{+}{W}-\vec{P})$, equals the rate of increase in productivity, $(\dot{\mathrm{X}})$. Consequently, faster productivity growth will increase the pace of growth of the purchasing power of wages, with little or no effect on the pace of wage and price inflation, per se. Since inflation is solely a monetary phenomenon, the only workable solution is to slow the growth in the supply of money.

At the other extreme, some supply-side critics argue that tax cuts, like those in the administration proposals, will lead to an increase in inflation. ${ }^{16}$ This conclusion is based on the argument that tax cuts increase demand for the nation's output, since only part of the proceeds of a tax cut is saved, while the rest is spent. Two corollaries of this view are that a tax cut raises the deficit and that it causes higher interest rates. Given the nation's income or tax base, it is easy to see that the deficit increases. Also, the government must replace the funds involved in a tax cut by borrowing (assuming government expenditures remain the same), but only part of the cut is available for lending, that is, the portion saved. Consequently, interest rates will tend to rise to attract the additional lending required and to bid funds away from private sector borrowers.

The conceptual shortcomings of this view are equally well known. The burden of government expenditures on household budgets is not measured by current taxes, but rather by the expenditures themselves. If current taxes are insufficient to pay for current expenditures, then either future taxes must be raised to pay the interest costs on a larger debt, or the debt can remain the same, if the Federal Reserve finances the additional portion by expanding the money supply faster. In the latter case, households pay the remainder of current taxes through higher inflation rates. Since the wealth and income of the economy is unaffected by a tax cut, it cannot lead to higher spending. A second problem is that even if individuals incorrectly perceive their wealth as larger after a tax cut and attempt to spend more on goods and services, a tax cut would indeed imply a shortage of funds in financial markets to finance the larger deficit. Interest rates would have to rise by enough to reduce spending to its original level.

For example, if taxes were cut $\$ 50$ billion and neither government expenditures nor the Federal

16An example of this argument is found in "Ease Off Kempm Roth," The New York Times, May 15, 1981.
Reserve's holding of government debt were changed, the govemment would have to borrow an additional $\$ 50$ billion. Now if individuals initially planned to spend $\$ 40$ billion while saving only $\$ 10$ billion of the tax cut, the excess borrowing requirement would be the amount of increased private spending, $\$ 40$ billion. As the government attempts to raise the additional $\$ 40$ billion in credit markets, interest rates would rise to increase household savings or reduce the borrowing and spending of other borrowers. Whether the $\$ 40$ billion is attracted through more saving (less consumer spending) or less business borrowing (less investment spending), total spending will tend to be unaffected by the tax cut. In summary, a tax cut may cause interest rates to rise, but is unlikely to affect total spending demands and, therefore, inflation.

The difficulties encountered by the higher deficits/ interest rates/inflation argument are not simply logical shortcomings. First, the tax cuts envisioned by the administration are accompanied by spending reductions, so there will tend to be little effect on the deficit or on interest rates. Second, the Kemp-Roth "cuts" in taxes are likely only to offset bracket creep over the next three years; thus, they are not really cuts in current taxes at all, simply offsets to keep average and marginal rates from rising due to current and prospective inflation. ${ }^{17}$ Finally, the experience surrounding the 1964 Kennedy tax cut and the 1975 tax cut would not support the higher deficits/interest rates/inflation scenario even if the administration were proposing a cut in taxes. In the 1964 case, the deficit rose very slightly and briefly, but interest rates did not rise until well after the tax cut. ${ }^{18}$ Inflation did begin to worsen, but only in response to the acceleration in money growth that began in 1963.

In 1975, federal taxes were reduced by increasing exemptions and the standard deduction. In that instance, the deficit rose sharply but interest rates did

\footnotetext{
17 This argument has been made by, among others, Martin Feldstein, "No Real Tax Cut" in Administration Plan," New York Joumal of Commerce, May 21, 1981. This point has also been made recently by Watter H. Heller, "Supply Side Follies of 1981," Wall Street Journal, June 12, 1981. Heller uses this point as part of an argument against the Kemp-Roth cuts. The cuts would keep marginal rates from rising further, however, so they would avoid a further deteriotation in incentives over the next few years. This argument merely indicates that Kemp-Roth type cuts will have to be much larger to eliminate the impact of past inflation on marginal tax rates and incentives, not that such cuts are ineffective.

18 Numerous studies have shown that the 1964 tax ent had no effect on total spending. Also, a recent discussion by paul Evans, "Kemp-Roth and Saving," Federal Reserve Bank of San Francisco Weekly Letter, May 8, 1981, shows that more than 100 percent of the tax cut was saved, that is, that consumption actually declined relative to disposable income.
} 
not. The 1975 tax cut was not associated with a more expansionary monetary policy. Instead, the growth rate of money stock for the year ending in the fourth quarter of 1974 was 4.7 percent; for 1975 it was 4.9 percent. These rates followed the rapid pace of monetary expansion at a 6.1 percent rate during the previous five years (ending in IV/1974). Consequently, inflation (GNP deflator) slowed, declining from a 7.7 percent rate in the year ending in the fourth quarter of 1974 to 4.7 percent in the year ending in the fourth quarter of 1975. Thus, even when a tax cut does not lower marginal rates, and/or the deficit increases as in 1975, it is not the case that interest rates must rise or that inflation must accelerate. ${ }^{19}$

\section{CONCLUSION}

Traditional macroeconomic policies affect the allocation, efficiency and growth rate of the supply of resources in an economy. These effects have been central to discussions of stabilization policies for centuries, but with few exceptions have been ignored in the post-war era. The reemphasis of these effects is what "supply-side economics" is all about.

There is little evidence to support the notion that supply-riented policies will work miracles in restoring productivity growth or in reducing inflation. Indeed, it is difficult historically to see any major disruptions of aggregate resource supply or allocation that are sufficiently profound to explain the stagtlationary performance of the U.S. economy since the early ${ }^{7} 70$ s. Only in the area of recent capital formation is there a clear resource supply shortfall and this is fully explained by supply forces other than government policy (energy price increases)..$^{20}$

19On the tenuous link between budget deficits and inflation, see Scott E. Hein, "Deficits and Inflation," this Review, (March 1981), pp. 3-10.

20The principal determinants of stagfationary developments since 1973 and $1979-80$ have been sharp increases in the relative price of energy - supply shocks. These increases fully account for the post-1973 decline in the pace of
At the same time, however, the historical record clearly indicates that supply-oriented policies can modestly affect resource availability, especially capital formation. Also, economic theory indicates a number of disincentives created by the tax system in an inflationary environment. While the magnitude of these disincentive effects is difficult to establish empirically, few economists or policymakers disagree with the importance of remedying these defects in macroeconomic policy.

The administration's economic policy proposals have incited a great popular debate over supply-side economics. Ironically, the proposals are quite modest in their supply-side orientation. The initial proposals address the disincentive effects of past policy and are not aimed at breaking the link between inflation and the supply of resources and output. Moreover, the proposed individual income tax cuts are sufficiently small so as to maintain marginal tax rates at current levels, rather than lower them.

No doubt, the issues raised by supply analysts will be of central importance for some time to come as policymakers face the continuing challenges to break the inflation-supply linkage, as well as to stay ahead of the deterioration in incentives to work, save and invest due to the cumulative effects of past fiscal, regulatory and monetary policy. It is likely that, when the smoke clears, it will be impossible to say that one can disregard the supply effects of policy any longer. But then the exaggerated claims or hopes of some supply analysts will be forgotten as well. Over a decade ago, Milton Friedman noted that, "In one sense, we are all Keynesians now; in another, no one is a Keynesian any longer." It is likely that a similar characterization will soon be an apt description of supply-side economics.

capital formation as well. For a more detalled discission, see John A. Tatom, "Energy Prices and Capital Formation: 1972-77," this Review (May 1979), pp. 2-11, and Tatom, "The Productivity Problem." 